\title{
Alberta's Resources Negotiations and Banff and Jasper National Parks
}

\section{Christopher Gainor}

The Governinent of Canada retained control of Crown lands and mineral and water rights in Alberta, Saskatchewan and Manitoba until 1930 when they were transferred to the three provincial governments as a result of agreements reached in 1929. In the case of Alberta, the agreement also settled the boundaries for Banff and Jasper national parks. The national parks discussions helped establish the principle that resource extraction would not take place in national parks anywhere in Canada. This paper examines the political background to the discussions over national parks and the process for setting the boundaries of these parks, with an emphasis on a report on park boundaries that addressed resource development and wildlife management in and near the parks, issues that parks administrators continue to face loday.

\section{Introduction}

The early histories of what are today Banff and Jasper national parks were marked by periodic boundary changes made by the government of Canada.' The last major adjustment of the two parks' boundaries occurred in 1930, when the National Parks Act was passed by parliament. This bill was passed shortly after the governments of Canada and Alberta settled a longstanding dispute over federal control of Crown lands and mineral and water rights in Alberta with an agreement that saw the federal government pass these rights to the Province of Alberta. The question of the national park boundaries was one of the smaller issues in the natural resources talks between the Alberta and federal govemments, but its resolution helped decide the question of resource extraction in national parks in every part of Canada.

In the negotiations over national parks in Alberta in the 1920s the federal governinent pressed for full control over national parks to protect them against resource exploitation; in exchange, it gave up large portions of the Banff park to the province. Today Canada's national parks, including Banff and. Jasper, face development pressures from growing numbers of tourists and the tourism industry. Developers wanting to build hotels, cottages, ski resorts, hiking and snowmobiling trails, and ranchers, miners and oil and gas companies are at work just outside park boundaries, and in some cases within the parks themselves. These pressures on the parks have become inajor preoccupations of the environmental movement. Wildlife management inside and near the parks is also a matter of controversy.

\footnotetext{
${ }^{1}$ W.F. Lothian, A Brief Hislory of Canada's National Parks (Ottawa: Ministry of the Environment and the Ministry of Supply and Services, Government of Canada, 1986), 33 \& 54.
} 
Many of these present day debates are strongly affected by the decisions made in the parks boundary bargaining of the 1920 s. $^{2}$ During the process of setting the park boundaries, the issues of wildlife management and development inside and near the parks were raised in an important but little-known report on the park boundaries that will be discussed in this essay.

\section{Alberta and its Natural Resources}

The matter of control over Alberta's lands and resources goes to the centre of Alberta's politics and identity. The concerns raised by the federal government's control of Alberta's resources early in the province's history have contemporary echoes in continued federal interest in Alberta's oil wealth. In spite of this, there is very little in the academic or popular literature about Alberta's efforts in its early years to win control of its resource wealth.

The original partners in Confederation - Ontario, Quebec, Nova Scotia and New Brunswick - retained control over Crown lands and mineral and water rights in their jurisdictions when they joined together in 1867, as did British Columbia and Prince Edward Island when these colonies entered Confederation in 1871 and 1873 respectively. When the Conservative federal government of Sir John A. Macdonald created the Province of Manitoba in 1870 out of federal lands acquired from the Hudson's Bay Company it retained control over the province's Crown lands and mineral and water resources. Similarly, when Sir Wilfrid Laurier's Liberal government created the provinces of Alberta and Saskatchewan out of part of the Northwest Territories on September 1, 1905, it also retained federal control of Crown lands and mineral and water wealth in these provinces. "[A]s compensation for the withholding of control over their natural resources, the provinces were each to receive the sum of $\$ 375,000$ annually, with provision for increase as the population grew."

The federal government justified what its critics called "second-class status" for the three prairie provinces on the grounds that federal control of western lands was needed so that federal control of immigration and settlement could be maintained and because the administration of natural resources would be too expensive for provinces with small populations. ${ }^{4}$ While Liberals praised the compensation terms as providing a steady income for the new governments,

\footnotetext{
${ }^{2}$ See Ed Struzik, "Parks in peril: Sacred trust under siege," Edmonton Journal November 7 , 2004, D6 and Ed Struzik, "Encroaching Development: Can You Serve Two Masters?" Edmonton Journal December 12, 2004, D3.

${ }^{3}$ L.G. Thomas, The Liberal Party in Alberta: A History of Politics in the Province of Alberla 1905-1921 (Toronto: University of Toronto Press, 1959), 10. See also "The Alberta Act, 1905." http://www.uni.ca/1905aa.himl. Accessed November 9, 2004.

${ }^{4}$ Franklin Foster, John E. Brownlee: A Biography (Lloydminster, Alberta: Foster Learning Inc. 1996), 86.
} 
F.W.G. Haultain, the outgoing territorial premier and a supporter of the federal Conservalives, criticized them. ${ }^{s}$

The Alberta Conservatives raised the natural resources issue in Alberta's first election in 1905 and again in the 1913 election, but they lost both campaigns. In 1913 Alberta Liberals under Premier Arthur Sifton changed their position to favour provincial control of natural resources, in part because a Conservative government was then in office in Ottawa. ${ }^{6}$ In the 1918 session of the legislature Liberal backbencher A.G. MacKay criticized Sifton's successor as premier, Charles Stewart, for his failure to raise the natural resources question at a meeting of premiers in Ottawa.?

During this time crown lands and mineral rights in Alberta were administered by the federal Department of the Interior. The question of Alberta's natural resources became more important after the war as forestry grew in importance and the oil industry increased exploration activities in Alberta following the Tumer Valley oil strike in 1914. John E. Brownlee, attomey general in the United Farmers of Alberta (UFA) government that took office in Edmonton in 1921, was soon involved in discussions over natural resources with Prime Minister William Lyon Mackenzie King's Liberal govermment, which also took office in $1921^{8}$

According to Brownlee's biographer, Franklin Foster, the sticking point in negotiations at the time was compensation for lands alienated before Alberta entered confederation. In the five years before 1905 more than ten million acres of Alberta land had been alienated by the federal government.

Of this, 6,400,000 acres of the finest and most fertile land in Alberta had been granted to various Eastern Canadian corporations as subsidies for the construction of railways not in Alberta, but in British Columbia, Manitoba and Ontario.'

By the 1920s, a total of ten million acres of Alberta land had been given to the railways and another ten million to homesteaders.

Other huge tracts had gone for Indian reserves, forest reserves, military reserves, and national parks, which in themselves accounted for tens of thousands of square miles of territory. Alberta had

\footnotetext{
'Thomas, II.

${ }^{6}$ Ibid., $29 \& 140$.

'Ibid., 183.

${ }^{8}$ Foster, 86. King's government required the support of Progressive Party members of Parliament to stay in office from 1921 to 1926. The Progressive Party was closely aligned with the UFA.

${ }^{9}$ Thomas, 87.
} 
provided fully ninety-five percent of the national park area then existing in Canada. ${ }^{10}$

While Brownlee was prepared to accept most of these alienations without compensation, he believed that there should be compensation for the Alberta lands granted to railways in exchange for their construction outside Alberta. Another issue was the federal government's awarding of large tracts of mineral rights for coal and oil and water rights for hydroelectric projects. ${ }^{11}$

Brownlee became Alberta's fifth premier in November 1925 when Herbert Greenfield resigned, and in January 1926 Alberta and the federal government reached a preliminary agreement over the resources question. ${ }^{12}$ Federal legislation to implement the agreement was delayed again when word reached Edmonton that the federal governinent had added a clause respecting school lands and the school lands fund, which raised the divisive issue of separate schools for Catholics in Alberta. The school question then got tied up in the courts. When the judicial committee of the British Privy Council, then Canada's court of last resort, threw the schools issue back to the contending governments, the two sides settled the matter in $1929 .{ }^{13}$

By then compensation issues involving all three provinces seeking control of their resources and lands had further clouded the picture. In 1929 Brownlee began new talks with Mackenzie King by announcing that the 1926 terms were no longer acceptable to Alberta. After a rocky start, discussions between the two leaders, and concurrent talks involving the Prime Minister and the premiers of Saskatchewan and Manitoba, took place in Ottawa in December 1929. The discussions were complicated by disagreements about the relative levels of compensation given to each province. Another problem, as King wrote in his diary, was that Charles Stewart, the federal interior minister and former Liberal Alberta premier, was "handicapped in his dislike of $\mathrm{B}$ [rownlee]." 14

The agreements on natural resources with Alberta and Manitoba were signed on Saturday, December 14, 1929 to avoid a Friday-the-thirteenth ceremony. A similar agreement was soon signed with Saskatchewan.

\footnotetext{
${ }^{10}$ Foster, 87.

"lbid., $87 \& 88$.

12 Ibid., $114-5$.

${ }^{13}$ Ibid., 124-6. Ted Byfield, ed. Alberta in the 20" Century, vol. 5, Brownlee and the Triumph of Populism (Edmonton: United Western Communications Lid., 1996), 91 \& 92.

King had won a clear majority in the 1926 federal election, and, as Byfield notes, this result reduced the importance of the natural resources question to King until 1929, when the prime minister began preparing for another federal election. Brownlec's UFA won the 1926 provincial election in Alberta.

${ }^{14}$ Byfield, 91-94 and Foster, 14I, 143 \& 166-67. Ironically, Brownlee supported the Liberals in federal politics, providing King with political advice. King, for his part, offered Brownlee a federal cabinet post. See Foster $121 \& 165$.
} 
The terms were iminensely more favourable to the Province of Alberta than those abandoned in 1926. The Dominion, having virtually fulfilled its Western lands policy objective, and finding administration costs more than any foreseeable future revenues, was amenable to a generous settlement. Also, bringing the western provinces to a position of equality with the others was an obvious and important step in completing the Confederation. In one bold stroke it would erase a political liability for the Liberals in the west and substitute a boost in prestige for the government across Canada. As King mused two days later on the eve of his fifty-fifth birthday, the settlement was a "great triumph."1

A more critical appraisal of the December 1929 talks gave credit for their ultimate success to the "initiative" of the premiers of Saskatchewan and Manitoba and the "procrastination" of King, rather than the efforts of Brownlee. ${ }^{16}$

When Brownlee arrived at the Canadian Pacific Railway station in Edmonton following the Ottawa signing ceremony he was greeted by a band, a bonfire, fireworks and a cheering crowd of more than 3,000 people gathered in subzero temperatures. ${ }^{17}$ As Foster notes, Brownlee's work in gaining the natural resources "laid the basis for the prosperity of every Albertan alive today." 18 The discovery of large reserves of oil and gas in Alberta, starting with the Leduc No. 1 oil well in 1947, led to Alberta's prosperity later in the century and sparked confrontations with the federal government over that wealth, most notably with the National Energy Program of the 1980s. ${ }^{19}$

The 1929 agreement between Alberta and Ottawa covered more than underground resources. A little-known part of deal addressed the furure of the national parks in Alberta and, by implication, all over Canada.

\footnotetext{
${ }^{15}$ Foster, 168-69.

${ }^{16}$ Carl F. Betke. The Uniled Farmers of Alberta. 1921-1935: The Relationship Between the Agricultural Organization and the Government of Alberta (M.A. Thesis, University of Alberta, 1971), 99-100.

${ }^{17}$ Foster, 169.The federal government also reached a similar agreement in 1930 with the government of British Columbia over control of lands known as the Railway Belt and land in the Peace River area that had been granted to the federal government to assist in railway construction.

${ }^{18}$ Ibid., 171.

${ }^{19}$ In 1980 the Liberal government in Ottawa introduced the National Energy Program, which restricted oil prices in Canada and encouraged Canadian control of the petroleum industry. Opposition by the Alberta govemment and the oil industry led the Conservatives to revoke the measures after they took over the federal government in 1984.
} 


\section{National Parks in Alberta}

The federal government set aside land in 1885 for what was designated in legislation two years later as Rocky Mountains Park, today's Banff National Park. By the time Alberta was founded in 1905 Waterton Lakes Park had also been established. The federal govermment set up Jasper Park in 1907, Buffalo game reserve near Wainwright in 1909, Elk Island game reserve near Edmonton in 1913 and Wood Buffalo game reserve in $1922 .{ }^{20}$ Before the talks with Alberta began in the 1920s the federal government had adjusted the sizes of both Banff and Jasper parks on several occasions. Following adjustments in 1914 the size of Jasper stood at 11,396 square kilometres, and Rocky Mountains Park was 7,125 square kilometres after a 1917 boundary change. ${ }^{21}$

In her study of the UFA govemment Susan Kooyman discussed the issue of national parks in Alberta as being part of a struggle between factions of the UFA government and organization over the question of whether hydroelectric power should be developed privately or by the government. ${ }^{22}$ The Calgary Power Company, a privately owned company, supplied Calgary with its electrical power needs using several power sites on the Bow River, but concerns were growing during this time about the adequacy of these facilities to supply power to the growing city. ${ }^{23}$ In 1923 Calgary Power applied to the federal government to develop the Spray Lakes, then in Rocky Mountains Park, to generate hydroelectric power. In its 1923 session the Alberta legislature passed a motion calling on the federal government not to grant a power licence to a private firm, because hydroelectric power should be developed "for the benefit of the people." Even though Attorney-General Brownlee expressed skepticism about public power, Premier Herbert Greenfield wrote Interior Minister Stewart in Ottawa asking that the power licence for the Spray Lakes be granted exclusively to the Alberta government. The UFA government's interest in public power began to diminish early in 1925 after it received a report commissioned the year before from Ontario Hydro engineers which stated that a hydro-electric power operation at Spray Lakes

${ }^{20}$ Lothian, 32, 52-54, 45-50 \& 64. Buffalo National Park was closed in 1940 and given to the Department of National Defence. The boundaries of Waterton, Elk Island, Buffalo and Wood Buffalo parks were not part of the resource discussions between Alberta and the federal government in the 1920s. Elk Island, Wood Buffalo and Buffalo national parks were originally designated as game reserves but were later designated as national parks. See Leslie Bella, Parks for Profit (Montreal: Harvest House, Ltd. 1987), 47 \& 56.

${ }^{21}$ Lothian, 33 \& 54. The Jasper and Rocky Mountain Parks were increased in size at the time to help the Canadian Pacific and Canadian National railways defend their near-monopoly on tourism services in the parks against outside tourism operators and the automobile, which both were on their way to overtaking the railways by 1930. See Bella, 60 .

${ }^{22}$ Susan M. Kooyman, The Policies and Legislation of the United Farmers of Alberta Government, 1921-1935 (M.A. Thesis, University of Calgary, 1981). 75.

${ }^{2.3} \mathrm{Ibid} .$, 75. Calgary Power is now known as TransAlta Utilities. 
would be profitable only if it were operated in conjunction with other power developments, which were in private hands. ${ }^{24}$

Shortly after Brownlee became premier Stewart wrote him to say that the federal government would issue a power licence to Alberta only if the Spray Lakes facility were to be operated as a public utility. Brownlee responded by asking that the Alberta government's request to develop the Spray Lakes be granted so that Alberta could have the same rights as other provinces to direct power developments within their borders. According to Kooyman, "Brownlee had changed the issue from one of private versus public development of water power to one of [federal] versus provincial rights over resources." 25

The pressure on Brownlee to solve Calgary's power-supply problem continued to grow in the mid 1920s. Brownlee's files in the Provincial Archives of Alberta contain many letters from the City of Calgary and the city's Board of Trade demanding that hydro-electric power be developed on the Spray Lakes to deal with the problem. ${ }^{26}$

Before 1920 the federal government permitted a limited amount of resource extraction, including mining and hydroelectric power development, in the parks and forest reserves. In 1911 the federal government passed the Dominion Forest Reserves and Parks Act through parliament to replace the original parks legislation, the Rocky Mountain Parks Act of 1887, and it established a Parks Branch under commissioner James B. Harkin.

After the First World War the Parks Branch became far less accommodating to resource development in the parks. In his study of the genesis of the National Parks Act of 1930 C.J. Taylor wrote that the Irrigation Branch of the Department of the Interior tried to gain control of water rights in the parks in 1920, and this, along with Calgary Power's application to develop Spray Lakes, caused the Parks Branch to argue for new legislation that would enshrine what is known as the principle of inviolability, protecting the parks from private development unrelated to tourism. While Harkin was able to defeat the Irrigation Branch, the Spray Lakes case proved more difficult. In 1923 a bill that would have enshrined the inviolability principle and blocked the development of parks without an act of parliament was introduced but not debated or passed by parliament. Taylor wrote that Interior Minister Stewart agreed with the principle of inviolability but was concerned about the power that the legislation gave the Parks Branch. "Harkin's response was to propose a reduction in the size of parks rather than compromise on the principle of inviolability. Principle rather than size had

\footnotetext{
${ }^{24}$ Ibid. 76.

${ }^{25} \mathrm{Ibid} ., 77$

${ }^{26}$ For a discussion of the background of the Spray Lakes proposal see Bella, 48-58.
} 
become his priority."27 The size of the parks and the principle of inviolability became central to the negotiations with Alberta over the national parks.

\section{Alberta Calls for a Parks Survey}

In 1927, when the federal government introduced another bill amending the Dominion Forest Reserves and Parks Act to provide that resources within the parks could not be disposed of without an act of parliament, Premier Brownlee wrote Prime Minister King on March 2 raising his concerns about how the proposed bill would affect the Spray Lakes development and the coal deposits that were thought to lie within park boundaries. Brownlee said he understood the 1926 natural resources agreement between the two governments as allowing mineral resources within the parks to be "available to the province without any undue restriction." Brownlee, perhaps sensing that his position on this issue was not strong, suggested that a "resurvey" of the Spray Lakes area and possible coalbearing areas would help balance the competing demands on the parks. He added that the idea of a resurvey had won "unanimous" support in the Alberta legislature: ${ }^{28}$

The Government of this Province would be willing to co-operate with your government whole-heartedly in such a resurvey and endeavouring to safeguard, as far as possible, the scenic beauty of such areas as finally defined, as we realize these National Parks form one of the great Provincial assets in the number of tourists that are attracted annually. We are sure, however, that our request for a resurvey is a reasonable one, and will be glad to hear from you that you are prepared to accede to this request. ${ }^{29}$

In subsequent correspondence between Brownlee and Stewart in this matter Stewart offered to amend the bill before parliament, but he then removed the bill from consideration and agreed to discuss the matter with Brownlee when visiting Alberta. Finally, on June 28, Stewart agreed to postpone discussions until the parks could be examined by Richard W. Cautley of the Department of the Interior and by a representative of the Alberta government. Brownlee had got his resurvey. ${ }^{30}$

\footnotetext{
${ }^{27}$ C.J. Taylor, "Legislating Nature: The National Parks Act of 1930," in To see ourselves/To save ourselves: Ecology and Culture in Canada. Canadian Issues/Thèmes canadiens, vol. xiii, eds. Rowland Lorimer, Michael M'Gonigle, Jean-Pierre Revérel, and Sally Ross (Montreal: Association for Canadian Studies, 1991), 129-132.

${ }^{28}$ Provincial Archives of Alberta, Premiers' Papers, Letter from J.E. Brownlee to Rt. Hon. W.L. Mackenzie King, March 2, 1927, File 488.

${ }^{29} \mathrm{Ibid}$. This passage contains a reference to tourism, a matter Brownlee rarely raised in his correspondence in this matter.

${ }^{30}$ Provincial Archives of Alberta, Premiers' Papers, Letter from J.E. Brownlee to Hon. Charles Stewart, May 4 and June 17, 1927; Letter from Hon. Charles Stewart to J.E. Brownlee, March 25, May 10, and June 28, 1927, File 488.
} 


\section{Cautley Reports}

Soon Cautley, a surveyor and "departmental officer with wide experience" who had previously represented Alberta on the B.C.-Alberta Interprovincial Boundary Survey between 1913 and $1924,{ }^{31}$ went to Edmonton and met the acting premier, George Hoadley, who deputized L.C. Charlesworth, the chairman of the lrrigation Council of Alberta, to be the provincial representative in discussions about the boundaries. Cautley visited Rocky Mountains Park and Jasper Park in August and September $1927 .^{32}$ In his report of June 1928 to the deputy minister of the Interior, W.W. Cory, Cautley took note of Cory's instructions:

Broadly speaking the principle to follow is that the areas investigated shall be classified on the basis of their being used for such purposes as shall yield the greatest returns to the nation. Many areas are so outstanding in their scenic, recreational and educational characteristics that there can be no doubt their natural and proper place is in national parks. Other areas may be more suitable for forest reserve than parks. Again, there may be areas where certain natural resources indicate that such arcas will serve Canada best by being open to industrial development. ${ }^{33}$

The first part of Cautley's report included a thorough explanation of how he decided on the parks' boundaries, which have become, for the most part, the permanent boundaries of Banff and Jasper national parks. Cautley reported that he inspected 750 miles of the eastern park boundary. He did not survey areas previously surveyed by M.P. Bridgland along the easterly side of the area known as the Jasper Park extension, or areas surveyed by H.F. Lambert along the northern boundary of Jasper Park. ${ }^{34}$ It was not necessary for him to inspect the parks' western boundaries since those were also the provincial boundary between Alberta and British Columbia and had already been surveyed.

"Lothian, 33. For more information on Cautley see Don Thomson, Men and Meridians : The History of Surveying and Mapping in Canada (Ottawa: Queen's Printer, vol. 2, 1967. vol. 3, 1969), and James G. MacGregor, Vision of an Ordered Land: The Story of the Dominion Land Survey (Saskatoon: Western Producer Prairie Books, 1981). See also "Cautley, Richard W."

hitp://www:peakfinder.com/peonle.asp?PersonsName=Cautley $\% 2 \mathrm{C}+$ Richard $+\mathrm{W}$. Accessed November 27, 2004. This site notes that a peak near Mount Assiniboine on the Continental Divide was named in his honour.

${ }^{32}$ Provincial Archives of Alberta, Premiers' Papers, R.W. Cautley, D.L.S. "Report to W.W Cory. Esq., Deputy Minister of the Interior on the Sclection of Permanent Boundaries of Rocky Mounlains Park, Jasper Park and Jasper Park Extension, accompanied by seven maps and one album of photographs," Department of the Interior: Ottawa, 1928, File 488, I-3.

${ }^{33}$ Ibid. 3.

${ }^{34}$ Ibid., 3. 
Cautley also referred to the Parks Branch's push for inviolability when he stated in his report that park boundaries needed to be reconsidered in order to vest natural resources to Alberta. Such reconsideration would lead to lands outside the park boundaries no longer being under the control of the federal government. "[I]t is proposed to alter the character of the govemment's title to lands within the Parks by making the National Parks of Canada inviolable, along the lines adopted by the United States in regard to their parks." He added that the federal government was proposing that future changes to the "externt and tenure" of national parks could only be made by an act of parliament. ${ }^{35}$

"In mountainous regions park boundaries must always be what are known as 'natural' boundaries; either heights of land or water boundaries of stream or lake," Cautley wrote, adding that he was ruling out straight-line boundaries because they were difficult to survey and maintain, they did not form natural barriers to hunters or game, and they would be difficult to mark in certain areas. ${ }^{36}$

Cautley said that the parks' natural boundaries should be "instantly recognizable," conform to the natural limits of game ranges, promote efficient park administration, including game and forest protection and road and trail construction and reduce to a minimum the need to put in "straight-line connecting links" across valleys or elsewhere. ${ }^{37}$

He also reported that there was "considerable difference of opinion between senior members of the Parks Branch staff" over the choice of stream or height-of-land boundaries for the park. Streams displayed "greater continuity of direction" than most mountain crests, but when streains divided and became smaller, they were less suitable for this purpose, he said. Stream boundaries appeared better to those who visualized the boundaries on maps rather than on the ground, he explained, and he studied his maps for streams that would make good boundaries. "After two months of riding along many such streams," he wrote, "it is my considered opinion that only a large river - practically unfordable constirutes a good park boundary, and that in every other case a height-of-land boundary is preferable." ${ }^{38}$

While height-of-land boundaries could be tortious, he said there were few cases where it was difficult to recognize such a boundary. A height-of-land tended to restrict the movement of humans and animals, while a stream was a travel route for both. A great deal of patrolling for forest protection purposes took place on trails that followed streams, and if the streams formed the park boundary the administrators of the land on either side of the boundary would have to patrol along the same trails, or an arrangement would have to be made between the two.

\footnotetext{
${ }^{35}$ Ibid., 4.

${ }^{36}$ Ibid., 5.

${ }^{37} \mathrm{Ibid}$.

${ }^{38}$ Ibid., 5-6.
} 


\section{"Here again, heights-of-land boundaries form natural boundaries between fire zones." 39}

In his discussion of park boundaries and game Cautley wrote that heightof-land boundaries were preferable from the viewpoints of wardens, hunters and the game animals. For wardens, stream boundaries meant patrols along streams where only one side was inside the park. Even good hunters would face dilemmas when camped alongside streams that formed park boundaries - among them was the question of what to do with a wounded animal that fled inside the park boundary. While hunted game crossed height-of-land boundaries, they did so less frequently than they crossed stream boundaries. As for the game animals, he noted that heights of land formed range boundaries more often than streams. ${ }^{40}$

The value of Park game is that it soon gains amazingly great confidence and is, therefore, visible to tourists and nature lovers, and this visibility of game affords one of the chief charms of our mountain parks. Most visitors to our Parks are more thrilled by getting close to one mangy old goat than by the contemplation of the most majestic glaciated mountain. ${ }^{41}$

Cautley noted that almost every day he spent inside park boundaries he saw game such as bears, sheep, goats, deer and moose, but such sightings were rare when his travels took him outside the boundaries. While this did not mean there were no game animals outside the parks, he said it indicated that animals outside the parks associated humans with danger: ${ }^{42}$

It can be accepted as a fact that in a valley where hunting is permitted on one side of the stream all the game is 'wild' and has lost its value as Park game. One other point is that it is not consistent with sound principles of game conservation to protect animals on one side of their range - thus giving them undue confidence - in order that they may be shot in another. ${ }^{43}$

Of the principal game animals of the parks - elk, inoose, deer, caribou, grizzly and black bears, mountain sheep and goats - Cautley said only the goats were found in the higher altitudes. Mountain sheep occupied large areas of

\footnotetext{
${ }^{39}$ lbid., 7-8. Emphasis in original.

${ }^{40}$ Jbid., 8 .

${ }^{41}$ Ibid.

${ }^{42}$ Ibid., 9.

${ }^{43} \mathrm{Ibid}$. Cautley's anthropomorphism follows that of Harkin, who wrote: "One of my happiest experiences has been to sce how wild animals bave responded to the protection afforded them in the national parks. It was touching to observe how soon they discovered that within these areas they were safe." See J.B. Harkin, The History and Meaning of the National Parks of Canada (Saskatoon: H.R. Larson Publishing Company, 1957), 10 \& 11.
} 
secondary mountain country, which were originally included in the parks for this reason. $^{44}$

In selecting permanent boundaries I have felt it necessary to exclude many such areas of secondary mountains, because they present possibilities of development either of timber, grazing or mining, but the fact should be realized that these exclusions involve the loss to the Parks of much valuable game country that has been built up by the Parks policy. ${ }^{45}$

The Rocky Mountains Park warden estimated that adoption of Cautley's proposed boundaries would mean a probable loss of more than half the game in the park, and the Jasper Park warden reported a heavy but not so great loss of game, according to Cautley. Most protected fur-bearing animals were predatory and were protected in the parks, Cautley reported, and when he visited the parks he observed very little ground game such as grouse, spruce hens, rabbits and squirrels. "I believe that a certain amount of winter trapping would be a positive benefit to the parks," he wrote, noting that small birds and ground animals "add much to the interest of trail travel," unlike shy and rarely seen animals such as weasels, wolves, wolverines, lynx, foxes, martens and mink. ${ }^{46}$

On the matter of trails and roads, Cautley wrote that in mountain areas trails must follow the floors of valleys, and these valley trails switch from one side of a stream to the other. The existing eastern boundary of Jasper Park followed the Southesk River to its source and then continued down the Rocky River. He said the nearest trails to these rivers lay outside the park and it was "impracticable" to build trails on the park side. "In this connection, it should be borne in mind that at least some of the packtrails of to-day will become the automobile roads of tomorrow." 47

In a section of his report on boundaries in relation to forest reserves, Cautley discussed the value of forests to the parks:

As far as the comparatively light forest growth on the eastern slopes of the Rockies is concerned, I am inclined to regard its principal value as the conservation of value and the prevention of soil erosion. Second comes the value of merchantable timber that can be obtained from it. Third is its value as providing cover for wildlife, and fourth is its beautifying effect on the mountain country. Of the above it is clear that all of these values, except only the second, can be preserved

\footnotetext{
${ }^{44}$ Cautley, 13.

${ }^{43}$ Ibid.

${ }^{46}$ Ibid., 14.

${ }^{47}$ Ibid., 10.
} 
for all time by a Parks administration just as well as by a Forestry Branch administration of equal efficiency. ${ }^{48}$

He discussed at some length his belief that timber growing above the 5,500-foot contour had no commercial value and that less than ten percent of the area of the two parks lay below that contour:

A few million feet of timber, so situated to be of doubtful value to any practical lumberman, is a ridiculously small price to pay for the glorious heritage of National Parks such as ours. It should be noted also that these main valleys, in which a certain amount of good timber grows, form the inevitable route for trails, highways and tourist traffic generally, so that to denude them of trees would be inexcusable folly. ${ }^{49}$

\section{Cautley's Boundary Proposals}

Cautley's proposed boundary changes for Rocky Mountains Park included removal of the Kananaskis River valley. Even though this area had been part of the park for 35 years, he said, it was separated by high mountain ranges, and since it contained the Bow River valley and its coal beds it should be removed from the park. He also suggested that the Ghost River and Red Deer River watersheds be removed from the park. The areas to be removed included the towns of Canmore and Exshaw, where mining had been permitted. Hydro-electric developments had also already been permitted at Kananaskis Falls and at Lake Minnewanka, which Cautley said should be kept in the park. ${ }^{50} \mathrm{He}$ said "a particular fine group of high mountains" in the Mount Malloch area on the north side of the Clearwater watershed should be added to the park. These recommendations drew no objections from Charlesworth, the Alberta government representative. ${ }^{51}$

\footnotetext{
48 Ibid., 10-11.

${ }^{49} \mathrm{Ibid} ., 13$. One of the major issues facing Jasper and Banff Parks has been forest fire management. See I.S. MacLaren, "Cultured Wildemess in Jasper National Park," Journal of Canadian Siudies Vol. 34, No. 3 (Fall 1999), 33-37. After a "spike" in forest fires at the time of the completion of the Canadian Pacific Railway, govemment policies against forest fires have altered the makeup of the forests in the parks.

${ }^{50}$ Taylor, $129 \& 132$. Cautley, 18 \& 21. The Premiers' file on the negotiations contains a letter sent to Stewart and forwarded to Brownlec discussing a "unanimous" resolution of the Canmore advisory council of the Racky Mountains Park Liberals that Canmore should remain inside the park. See Provincial Archives of Alberta, Premiers' Papers, Letter from Siewart to Brownlee, January 15, 1930, File 488.

${ }^{51}$ Cautley, 23-24. See also Canada, Department of the Interior, Map Showing Areas Which It Is Proposed to Withdraw from Rocky Mountains and Jasper Parks (Ottawa: Government of Canada, 1929). The Kananaskis Valley, including the Canmore and Exshaw areas, is
} 
Cautley also recommended that the area known as the Jasper Park extension, the area south of Sunwapta Pass that included part of the Columbia Icefield, be shifted to Rocky Mountains Park. The incorporation of this area into Jasper Park had brought protests from guides in Banff. Cautley noted that his change would have administrative benefits and would reduce the size difference between the two parks, although Jasper would still be half again larger than its southern neighbour. ${ }^{52}$. He also suggested that a large part of the extension be removed from the national parks,

[T]he present boundaries of Jasper Park extension include a considerable area of secondary mountain country which may in the future be found to possess possibilities of industrial development such as lumbering, mining or grazing, which make it undesirable to include in the present boundaries." ${ }^{33}$

More controversial was Cautley's proposal to retain the Spray River watershed in Rocky Mountains Park. Although the questions surounding hydroelectric power proposals for this area were beyond his authority, Cautley said:

Looking at the matter purely from the point of view of park boundaries, I feel strongly convinced that any area within the parks in which it is proposed to pennit industrial development of any kind should first be excluded from the parks before such permission is granted, otherwise a precedent would be established which I can only regard as being subversive of the Minister's expressed intention to make the National Parks of Canada inviolable. ${ }^{54}$

Cautley's other recommendations for Jasper Park boundaries included removal of park areas near the Athabasca River and around Rock Lake due to

contained in the shaded area designated as " 630.0 sq. miles." The Ghost River area removed is marked as "76.6 sq. miles," and the Red Deer River watershed is marked as "290.7 sq. miles." Mount Malloch and the Clearwater Basin are immediately to the west, but are not highlighted in the map since the addition to the park was made before the other areas were removed.

${ }^{52}$ Cautley, 25-27 and Lothian, 54.

${ }^{53}$ Cautley, 27. On the interior Department map, the area to be removed is marked " 377.0 sq. miles."

${ }^{54}$ Ibid., 20. Emphasis in original. 
possible coal reserves and a change from straight line to height-of-land boundaries near the Rocky and Southesk rivers in the east part of the park. ${ }^{55}$

Appended to Cautley's report is correspondence between him and Charlesworth from the fall of 1927 . While Charlesworth agreed in an October 18 letter to most of Cautley's proposed boundaries, he stated that the Alberta government would like the Moosehorn Valley area, which was suspected to have coal reserves, to be left outside Jasper Park, and he offered Alberta's "strongest possible objections" to Cautley's plan to keep the Spray Lakes inside the Rocky Mountains Park. Cautley's reply nine days later stated that the Moosehorn area would form an excellent entrance to the park and that the Spray Lakes area contained "many fine mountains" and would be a good location for a road. But he promised to put the Alberta government position before the Minister of the Interior. Charlesworth's response of November 26 continued to back both Alberta government positions and included a suggestion that Alberta would set up a game reserve in the Moosehorn area. The final letter attached to the report, from Cautley dated December I, called Alberta's game protection budget "insufficient."

\section{Further Discussions on Agreement}

Letters between Premier Brownlee and Interior Minister Stewart from February and March 1928 in the Alberta Provincial Archives strongly suggest that both knew what would be in Caulley's report, which was completed the following June. This and Taylor's statement that Cautley removed resource-rich areas from the parks "[f]ollowing Stewart's instructions" show that the boundaries were subject to bargaining between the two governments at a high level. ${ }^{57}$ On February 14 Brownlee wrote Stewart that he would be prepared to give way on the Moosehom Valley in Jasper but asked Stewart why he still wanted to restrict but not block development in Spray Lakes. Brownlee offered to cooperate with the federal government in maintaining the natural features of parks, but he still raised concerns about the possibility of mineral wealth in the parks. In his reply two weeks later Stewart stood his ground on his conditions for use of Spray Lakes and said that in retum for the boundary adjustments he expected Alberta to give up

\footnotetext{
${ }^{55}$ Ibid., 29-30. On the Interior Department map these areas are at the northern end of Jasper Park. In his covering letter with the report to Charlesworth Cautley said the Rock Lake area was removed "as a direct result" of Charlesworth's representations about the possibility of coal beds in the area, although Cautley indicated that he was skeptical about the claim. A small adjustment to these northern boundaries was made in a supplemental report by Cautley dated December 15, 1928.

${ }^{\text {s6 }}$ Cautley, Appendix.

${ }^{57}$ Taylor, 132.
} 
rights to minerals in parks. The province would retain control of general taxes, public health, education and liquor control within the parks. ${ }^{58}$

In the final letter, dated March 13, Brownlee retumed to his point about restrictions on mineral development in the parks, saying that he assumed "that the Government of Canada was only interested in preserving the natural beauty of the Park, and not in obtaining the revenue from any possible resources that might subsequently be discovered." If the federal parliament decided to develop that mineral wealth, Brownlee argued, then Alberta "should get the benefit of such development." ${ }^{.59}$

C.J. Taylor wrote that Harkin forcefully stood up for the principle of inviolability in the face of Alberta's demands for control of resources inside the parks. "On a number of points then, Harkin forced the government to take a much tougher stand with the province than it might have done if it had been left unhindered by Harkin's principles. ${ }^{160}$

It appears that the two sides reached agreement on these points soon after this time, and final agreement awaited completion of the wider resources agreement that was signed in December 1929. Early in 1929 the Jasper Park extension was transferred to the Rocky Mountains Park, and a small bit of territory around Mount Malloch was also added to that park. Small additions were also made to Jasper Park. ${ }^{61}$

In the spring of 1930 parliament passed the Albeita Natural Resources Act, which handed over Crown lands, mineral rights and water rights to the province of Alberta. The federal cession of rights and lands took effect on October 1 , and under legislation passed by the Alberta legislature the Alberta Department of Lands and Mines came into existence to regulate these new provincial assets. The former national park land given to Alberta included the areas suggested by Cautley and the Spray Lakes area. ${ }^{62}$ The federal act contained the 1929 agreement, which gave the Parliament of Canada jurisdiction inside the park but also specified that the parks and their mineral rights would go to the province if parliament decided the lands were no longer needed for parks. ${ }^{63}$ In the same session, parliament also passed the National Parks Act, which established the principle of

\footnotetext{
${ }^{58}$ Provincial Archives of Alberta, Premiers' Papers, Letter from J.E. Browulee to Hon. Charles Stewart, February 14, 1928 and Letter from Hon. Charles Stewart to J.E. Brownlee, February 28, 1928, File 488.

${ }^{39}$ Provincial Archives of Alberta, Premiers' Papers, Letter from J.E. Brownlee to Hon. Charles Stewart, March 13, 1928, File 488.

${ }^{60}$ Taylor, 132.

${ }^{61}$ Lothian, 33 \& 54.

${ }^{62}$ Taylor, 132.

63 “The Alberta Natural Resources Act." http://laws.justice.gc.ca/en/A-10.6/text.hıml . Accessed Noyember 19, 1929. Ansural Report of the Department of Lands and Mines of the Province of Alberta for the Fiscal Year ended March 31, 1931 (Edmonton: King's Printer, $1931), 9$.
} 
inviolability of parks lands. The two Alberta mountain parks became known as Banff National Park and Jasper National Park. ${ }^{64}$

By the time the land transfers were accomplished the federal government had granted Calgary Power licences to develop hydro-electric power in the Ghost River area, and these developments satisfied Calgary's growing power demands at the time. ${ }^{65}$ Wartime exigencies in 1940 led to "a serious breach to the principle of inviolability" when Calgary Power was granted permission to raise the level of Lake Minnewanka to expand its power-generating capacity. But as Taylor said, "This development did not constitute a breach of the National Parks Act since it necessitated passage of a separate act of parliament."

Calgary's appetite for power continued to grow, and in 1949 Calgary Power began building power-generation facilities on the Spray Lakes. To make it possible the federal govermment agreed to remove a small amount of land from Banff National Park. The federal government also made a small adjustment to the eastern Banff boundary in 1933 to permit construction of a new park entrance building on the highway from Calgary. ${ }^{67}$ The final dimensions of Banff and Jasper national parks were established at 6,641 square kilometres and 10,878 square kilometres respectively, and there has since been little complaint from the Alberta government about the dimensions of national parks in the province. ${ }^{68}$

\section{Conclusion}

C.J. Taylor called the Alberta natural resources agreement a "sizeable victory" for the Parks Branch because "it recognized the extension of the principle of inviolability over a considerably larger area than the Minister had initially envisaged." ${ }^{69}$ The settlement of the parks boundaries together with the National Parks Act of 1930 established inviolability in parks in all parts of Canada. But the administration of national parks has represented something of a defeat for the cause of protecting the parks. Taylor wrote that the 1930 legislation protected parks from resource development but not from recreational development such as golf courses, skiing facilities and highways. ${ }^{70}$ Another critic of the parks, Leslie Bella, noted that Harkin and Arthur Wheeler, who opposed resource development in parks as a leader of the Alpine Club of Canada and the Canadian National Parks Association, had argued that "beautiful scenery was itself a source of profit" from

\footnotetext{
64 "The National Parks Acl," in Documenting Canada: A Hislory of Modern Canada in Documents, eds. Dave de Brou and Bill Waiser (Saskatoon: Fifth House Publishers, 1992), 299-302.

${ }^{65}$ Kooyman, 78.

${ }^{66}$ Taylor, 135

${ }^{67}$ Kooyman, 78 and Lothian, 33.

${ }^{68}$ Lothian, 33 \& 54. An exception was a 1962 resolution of the Alberta legislature calling for the return of the Alberta portion of Wood Buffalo National Park. See Lothian, 67.

${ }^{69}$ Taylor, 132.

${ }^{70} \mathrm{Ibid}, 135$ \& 136.
} 
tourists. "Wheeler and Harkin saved the national parks from one kind of exploitation, but by ensuring their exploitation from another."

It is interesting to note that much of the land removed from the Banff park, especially the Kananaskis Valley, has since been designated as provincial parkland. The near absence of discussion about tourism in the premier's correspondence of the 1920s over parks suggests that the Alberta government gave virtually no thought to the matter at the time, probably because most of the benefits from tourism in the parks at the time flowed to the federal government and the railways. Once easy automobile access to the parks was established and the tourism industry grew after World War Two the Alberta government took a more active role in promoting tourism.

Cautley's report on the park boundaries provides a fascinating view of attitudes to the parks in the late 1920s. Cautley pressed for the principle of inviolability, yet the new boundaries for the parks included Lake Minnewanka and the Spray Lakes where hydroelectric power development has been permitted to the present day. As has been outlined, the boundaries he proposed resulted in part from political trade-offs between the federal and Alberta governments that did not follow Cautley's ideas for effective park boundaries. Today many of the biggest issues involving our national parks involve wildlife management, and Cautley discussed this issue at some length. The utilitarian view he took of wildlife has its echoes today in debates over wildlife management in and around our national parks, including regulation of hunting and wildlife movement near highways and tourist areas. $^{72}$

Like most government reports, Cautley's report sits largely forgotten in government archives. Yet unlike many similar reports, Cautley's efforts were quickly acted upon and left a tangible legacy in the forn of today's Banff and Jasper National Parks. Governments and the public continue to face decisions about what to do inside the boundaries Cautley helped set. Development outside those boundaries, including lands included in the two parks before 1929, also has a major impact on people and wildlife inside and outside the parks.

\footnotetext{
${ }^{71}$ Bella , 57-58.

${ }^{72}$ See both Struzik articles.
} 